\title{
EI Nino Effect on Coffee Growth and Productivity on Several Agroforestry Systems in Gumitir Mountain Coffee Farms, East Java, Indonesia
}

\author{
Fitria Yuliasmara ${ }^{1 *}$ \\ ${ }^{1}$ Indonesian Coffee and Cocoa Research Institute, Jl. P.B. Sudirman 90, Jember, Indonesias \\ ${ }^{*}$ Corresponding author: yuliasmara.iccri@gmail.com \\ Received: 26 April 2017 / Accepted: 5 October 2017
}

\begin{abstract}
Climate change and global warming have become major issues in the last 10 years and affect many sectors including coffee plantations. Global warming causes El Nino to occur more frequently and potentialy reduced agricultural production between 5-20\%. In coffee plantations, an effort to minimize the impact of climate change is the use of agroforestry cropping pattern. One of the Robusta coffee producing areas grown using agroforestry system in East Java is at Gumitir mountain area. Coffee plants used as samples were 10-12 years old of Tugusari 6 coffee plantations managed by Sidomulyo farmer group. The environmental design used completely randomized block design with three replicates for each treatment which consisted of \pm 0.5 ha. The results of this study indicated that coffee grown under forest produced the lowest irradiation and keep daytime temperatures $26.33{ }^{\circ} \mathrm{C}$ with humidity $85 \%$ during this El Nino period. On plant growth parameters showed that the lower intensity of irradiation produced coffee plants with morphological characters of longer segments, larger leaves and higher chlorophyll content. Plant growth showed no significant difference except in coffee agroforestry system with pine which produced the smallest stem diameter and fewer productive branches. It was suspected due to the presence of allelopati compounds released by the litter of pine leaves. Coffee grown under natural forest produced highest nodes per branch, cherries per node, and number of cherries per tree than other systems. Productivity of robusta coffee in Gumitir mountain area during El Nino showed that the highest productivity in forest $1497 \mathrm{~kg} \mathrm{ha}^{-1}$ and $1355 \mathrm{~kg} \mathrm{ha}^{-1}$ on coffee grown under Leucaena, due to its ability to maintain moisture. Agroforestry system in coffee is able to maintain environmental conditions in this case in terms of irradiation, temperature and moisture during El Nino which caused stability of plant growth and coffee productivity during El Nino.
\end{abstract}

Keywords: El Nino, coffee agroforestry, growth, productivity

\section{INTRODUCTION}

El Nino is a climatic aberrations in the Pacific Ocean which is characterized by the increase in sea surface temperature in latitude of $5^{\circ} \mathrm{N}-5^{\circ} \mathrm{S}$ and longitude of $170^{\circ} \mathrm{E}-120^{\circ} \mathrm{E}$ (Trenberth, 1997). Since 1970 at least 10 times El Nino had occurred with a strong intensity. As reported by FAO (2016), drought as an effect of El Nino in 1997 has led to the collapse of rice production on a very large scale that covers an area of 426,000 ha. In addition to rice crop, other agricultural commodities such as coffee, 
cocoa, rubber and palm oil also decreased their actual production due to drought. El Nino increases intensity and frequency of drought and causes the death of coffee plants and reduced coffee production in that year and years after. A good climate forecast may provides an opportunity for farm managers to better implement crop management decisions in certain period (Hammer et al., 1996).

On the coffee plantations, efforts to reduce the impact of drought caused by global warming has started since early 2000's. One of the anticipation action towards global warming is the application of agroforestry system (coffee grown under shade). The agroforestry system creates an environment similar to the forest where coffee originated (Barros et al., 1995) so that the coffee plant grows well and sustainable. Coffee is typically cultivated in tropical and subtropical areas at high elevation, often in mountainous areas and naturally grows under canopy of shading trees. Traditional coffee is often integrated in to agro-forestry system in which tree species are cultivated together with coffee and other agricultural commodities which are home for many different floras that contribute to high biodiversity level. The shading of canopy also provides a valuable habitat for indigenous fauna, animals and insects, as well as preventing topsoil erosion and reducing the need for chemical fertilizers.

Agroforestry is a system that is considered to provide benefits not only for humans in terms of the economy but also environmental services (Vaast et al., 2006). This system has the potential benefit to the environment in the form of improving soil fertility, reduce erosion, improve water quality, increase biodiversity, and carbon sequestration. Coffee plants grown under forest have the potential to increase carbon uptake ranged from $10 \mathrm{Mg}$ ha $^{-1}$ (Hairiah et al., 2006), while in the 8-9 years smallholder coffee farms can absorb 9.79 to $12.68 \mathrm{Mg} \mathrm{ha}^{-1}, 8-10$ years coffee plants in the Kaliwining Experimental Station can absorb 7.47 to $12.53 \mathrm{Mg} \mathrm{ha}^{-1}, 8-12$ years coffee plants in the Sumberasin Experimental Station can absorb 9.21 to $15.82 \mathrm{Mg} \mathrm{ha}^{-1}$, and 10 years coffee plants in the Andungsari Experimental Station can absorb $19.24 \mathrm{Mg}$ ha $^{-1}$ (Wibawa et al., 2010). Until now, agroforestry has been developed in many places with various modifications, including in Indonesia (Garrett et al., 2000; Garrity, 2004; Williams-Guillen et al., 2008; Nair et al., 2009).

There are various agroforestry systems applied in Indonesia, namely (Pranata \& Yuliasmara, 2016): a) Simple shade agroforestry, coffee grown under one type of shade tree, where coffee as a major commodity; b) Multistrata agroforestry, coffee grown under more than one kind of shade trees with irregular planting patterns form a complex agroforestry system; c) Multiple cropping, coffee agroforestry systems with timber plants and all commodities in the system harvest as income of the farmers. d) Box system agroforestry, a system using industrial wood as a coffee plantations boundaries. Industrial wood as a reinforcement of industrial wood porch, wind breaker and enhancing the income of farmers. The minimum land area in this system $0.5 \mathrm{ha} /$ plot; and e) Coffee grown under forest (natural) forest. In this system, plants in the forest as a primary commodities while coffee plants become a additional revenue. On smallholder coffee farms, this practice may be a survival strategy, because the diversification provided by the system, with production of wood, fruits and other by products reduces risk and make family based coffee production possible.

Shade grown coffee (Agroforestry) has consequences on decreasing productivity of coffee. However, it can be compensated by an increase in coffee flavor, stability productivity, lower production costs, and increasing environmental service. Ditjenbun (2010) mentioned that total coffee plantations area 
in Indonesia was 1,210,365 ha, 96\% of them are smallholder plantations and $4 \%$ plantation cultivated by large estate, with an export volume of 433.595 tons/year, and the total production of 686.920 tons/year. Coffee productivity in Indonesia is lower than the other coffee producing countries in the world such as Vietnam (1,320,000 tons/year), and Brazil (3,049,560 tons/year).

Agroforestry system is believed to be both more resilient and sustainable. Agroforestry system appear to be an alternative for coffee cultivation, as much for its potential in promoting soil sustainability, as for the social and ecological aspects (Fournier 1987; Macedo et al., 2000; Cardoso et al., 2001). Coffee agroforestry system is applied for achieving multiple objectives including food production, ecosystem service delivery, biodiversity conservation and sustainable livelihoods. For small growers, this practice may be a survival strategy, because the diversification provided by the system, produce wood, fruits and other by-products, reduces risk and make family based coffee production possible. Coffee with agroforestry system is expected to be a characteristic of coffee plantations in Indonesia which has a high taste quality, environmental friendly and sustainable. Growth and productivity of Robusta coffee plants in Gumitir Mountain area, East Java in 2016 as the impact of El Nino in 2015 will be discussed in this paper. It is expected that the results of this study can be used as a basis for determining sustainable coffee planting patterns and to realize ecofriendly coffee farming in the region.

\section{MATERIALS AND METHODS}

Experiment was conducted in smallholder coffee plantations in the Gumitir Mountain area located on the border between Jember district and Banyuwangi district in East Java. Gumitir mountain area has an altitude between
400-600 m asl., type of soil Latosol, with the dry climate $\mathrm{C}$ according Schmidt-Ferguson classification. Temperatures range between $23-31^{\circ} \mathrm{C}$, with a dry season from May to August and the rainy season from September to January with the average annual rainfall $3,975 \mathrm{~mm}$ between 2005-2016.

Coffee plantations that is used as a sample in this research managed by "Sidomulyo" farmer group based on expert recommendations from local extension services. This study used 10-12 years old clonal coffee plants with Tugusari 6 (BP 534) as scion and Excelsa seedling as roostock. Pruning system used is a simple single stem pruning and it causes the coffee canopy overlapping each other and covering the entire surface of land. Spacing between coffee trees $2.5 \mathrm{~m} \times 2.5 \mathrm{~m}$ or equivalent to the population of 1,600 plants/ha.

Environment design used was a complete randomized block design with three replications for each treatment. Each plots consisted of 0.5 ha with standard good agricultural practices applied by farmer group. There were six coffee agroforestry systems observed in this area namely withhout shading, simple shade agroforestry (coffee-(Leucaena sp: $2.5 \mathrm{~m}$ x $2.5 \mathrm{~m}$ )), multistrata agroforestry (coffee with more than two crops and wood), coffee(Parasianthes falcataria: $2.5 \mathrm{~m} \times 5 \mathrm{~m}$ ), coffee(pine $6 \mathrm{mx} 4 \mathrm{~m}$ ), and coffee under natural forest.

Robusta coffee production in smallholder coffee plantations in Gumitir mountain area was observed at the observation variables: 1) Microclimate observations conducted on the intensity of light above the coffee canopy, temperature and humidity, 2) Coffee plant growth observations conducted on stem diameter, segment length, chlorophyll content (SPAD), and leaf width (Gravimetry), 3) Observations of productivity per tree conducted on number of productive branches, number of bunches per branch, number of cherries per bunch, and number of cherries per tree, 
4) Observations of productivity per hectare conducted on the area 0,5 ha and its population per hectare productive trees $(\%)$, number of productive trees, number of cherries per hectare and productivity per hectare $(\mathrm{kg})$.

\section{RESULTS AND DISCUSSION}

\section{Rainfall, Microclimate, and Fruiting}

Gumitir Mountain is one of the areas affected by the El Nino phenomenon in 2015. Rainfall in the area decreased drastically from the average annual rainfall during the last 12 years which reached $3,975 \mathrm{~mm}$ as low as $1,801 \mathrm{~mm}$. The distribution of rainfall associated with flowering patterns and fruiting patern of coffee plants in Gumitir Mountain coffee during period of April 2015-July 2016 can be seen in Figure 1.
Based on observations of rainfall on Gumitir mountain are in 2015 the dry season began in May-October with anomalous rain in June. Under normal weather conditions, dry season occurs in May-August and the rainy season begins in early September. Additional dry season for two months caused stress on the coffee plants. Stress is clearly visible by the physical appearance of the plants. The leaves started to fall and looked as if the whole plants were wilting. There was light intensity of rain in August that triggered blooming but it was not optimum. When the amount of rainfall was inadequate, then the flowers shed (Pereira \& Pereira, 2009) and the crop was lost for the coming year.

Microclimate in the coffee plantations during El Nino in Gunung Gumitir area, East Java is shown in Figure 2.

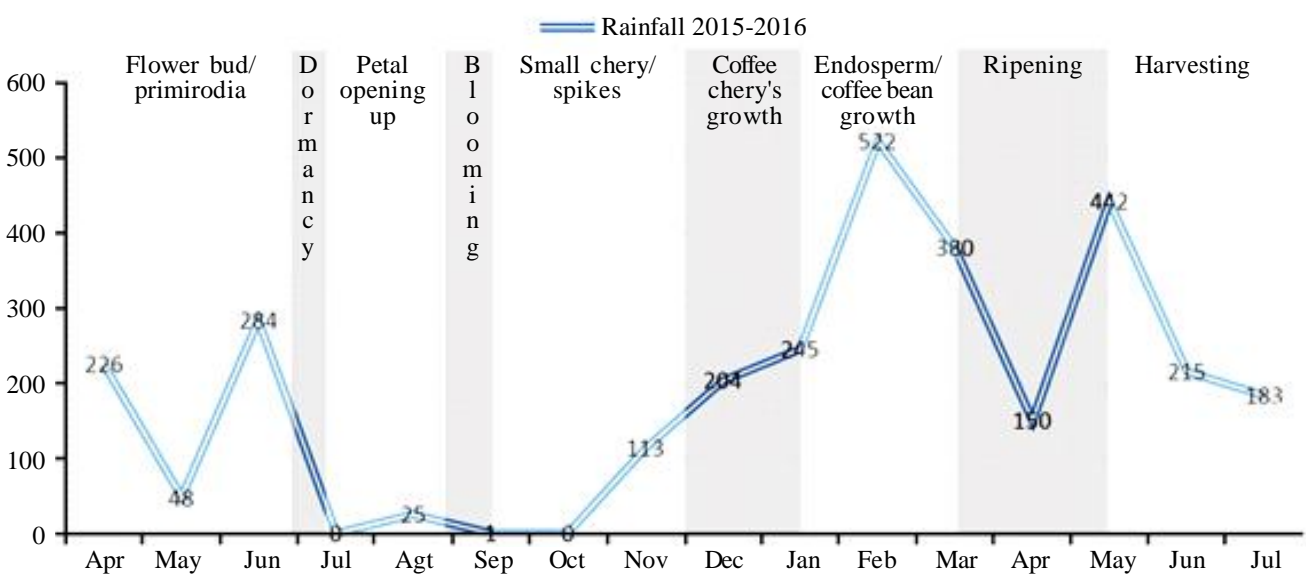

Figure 1. Rainfall distribution and pattern of coffee flowering and ripening 

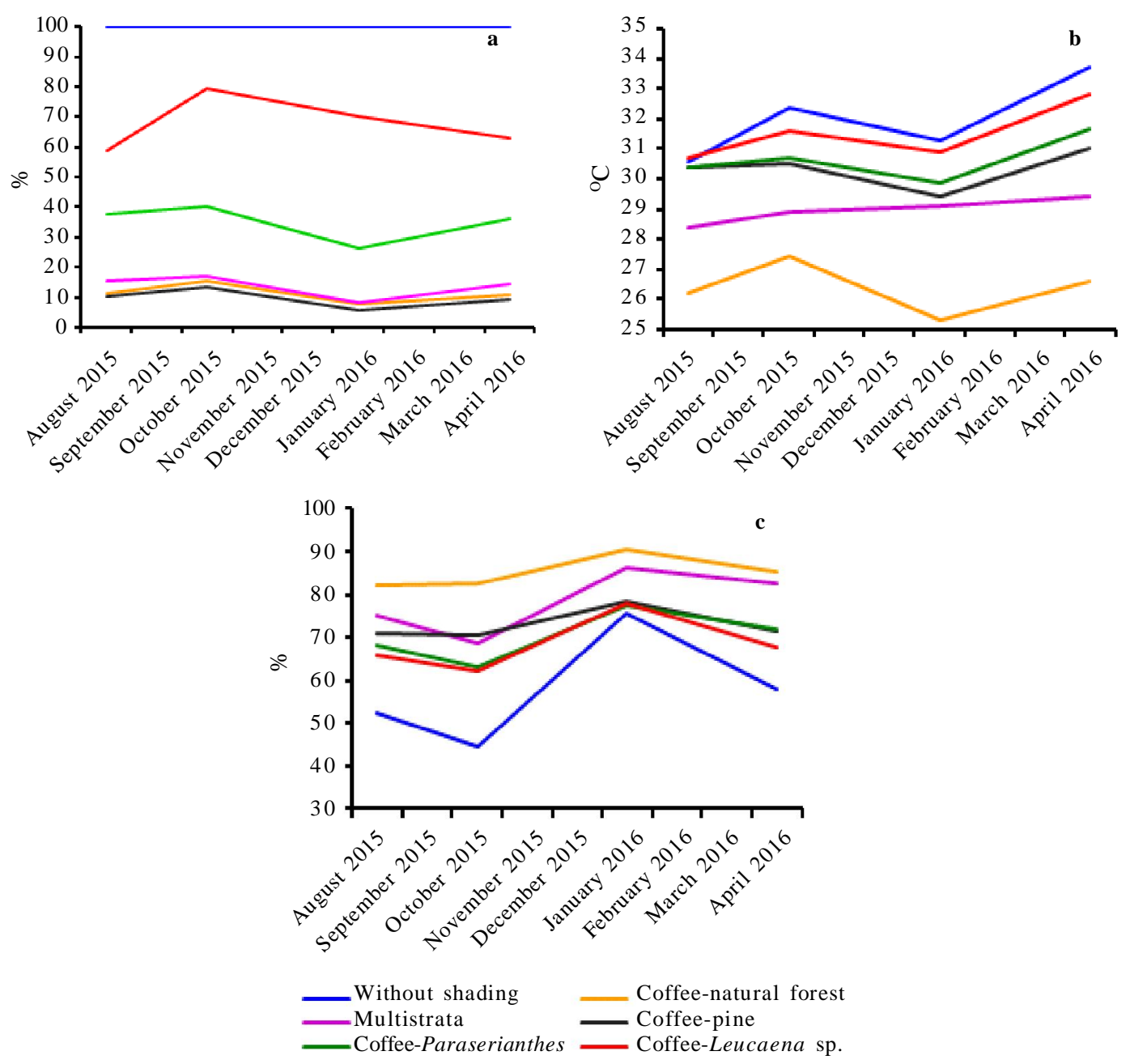

Figure 2. Microclimate on coffee agroforestry system; a. light intensity $(\%)$, b. temperature $\left({ }^{\circ} \mathrm{C}\right)$, and c. humidity $(\%)$

The most important resources in the above-canopy area of the coffee plants and shade plants is sunlight, while in the rooting area are water and nutrients. Reduction in light transmittance is dependent on the structure and thickness of branches and leaves of the shade trees (Larcher, 1995), and density and width of the canopy (Suryanto et al., 2005). Low light intensity occured in coffee grown under coffee-pine was $9.70 \%$, natural forest $11.27 \%$, and multistrata $13.84 \%$. Coffee grown under Parasianthes falcataria and Leucaena shows light intensity $35.02 \%$ and $67.83 \%$, respectively, which is approached the optimal percentage for coffee growth and productivity. According to Thomaziello et al. (2000) the amount of radiation intercepted by coffee plants and the radiation regime inside the canopy during its growth period, influences the energy stock, thus affecting flowering, photosynthesis rate, growth and fruit set (Rena \& Maestri, 1986). Optimum light intensity for the support of growth and productivity of coffee ranges from $45-65 \%$ (Thomaziello et al., 2000) and the upper limit of acceptable shade for coffee is considered to be $70 \%$ (Kumar \& Tieszen, 1980; Muschler, 1995). 
Temperature in agroforestry system can be attributed to a smaller direct incidence of solar radiation on the coffee canopy (Pezzopane et al., 2000). Temperatures are closely related with the humidity where temperature rise will cause a decrease in humidity. Temperatures in the shades of coffee grown under natural forest $26.33^{\circ} \mathrm{C}$ on average, lowest than the other agroforestry system. While the moisture in the system was $85.00 \%$ and higher than any other agroforestry systems. In the coffee plantations without shading about $6.0^{\circ} \mathrm{C}$ higher than coffee grown under natural forest. The others agroforestry system such as multistrata, coffee-pine, coffeeParaserianthes, and coffee-Leucaena showed the temperature in the range of $29-31^{\circ} \mathrm{C}$ with humidity in the range of 68.43 to $78.33 \%$. Coffee without shade had the highest average temperature of $32.05^{\circ} \mathrm{C}$ with humidity at $57.66 \%$. Optimal temperature for Robusta coffee plants in Indonesia is between 24$30^{\circ} \mathrm{C}$ (Hulupi, 1999), while in South America optimal temperature for Robusta between $25-27^{\circ} \mathrm{C}$ (Alegre, 1959) with humidity 70 $80 \%$ (Hulupi, 1999). Their shade can keep the ambient temperature lower during the day and higher at night. According to Lin (2007) ambient temperatures above $25^{\circ} \mathrm{C}$ can reduce photosynthesis significantly. Above $27^{\circ} \mathrm{C}$, fruit development and ripening are encouraged to be faster thus reducing the quality of the fruit. Conversely, if the ambient temperature around Robusta coffee is less than $25^{\circ} \mathrm{C}$ causes inhibition of plant growth (Lin, 2007).

\section{Vegetative Growth}

Coffee vegetative growth is influenced by several environmental factors such as irradiance, temperature, water and nutrient supply (Silvain, 1958). High irradiation intensity causes plants to quickly enter generative phase, and less sustainable productivity (Pranata \& Yusianto, 2012).

In this study, observations of plant height cannot be carried because coffee plants had been prunned/topping at $160-180 \mathrm{~cm}$ above soil surface. Diameter of the coffee plants at some agroforestry systems showed no significant difference $(\mathrm{p}<0.05)$ except in the coffee-pine which has the smallest diameter. This indicated that growth of coffee under pine was less optimal. Allelopati is one factor that often known to be responsible for growth inhibition of plants so that it may play an important role in the formation of sparse forest floor. As reported by Nektarios et al. (2005) that allelopati compounds from pine needles litter can inhibit growth of bermuda grass, in which it reduce the $51.8 \%$ of canopy growth and reduce $30.4 \%$ of root length. Aqueous methanol extracts of red pine litter inhibited the growth of cress (Lepidium sativum) and Digitaria sanguinalis $\mathrm{L}$., and the increased extract concentration enhanced the inhibition (Kimura et al., 2015). Litter of pine needles are suspected to have an allelopati compound that inhibits coffee plant growing. Two main inhibitory substances were determined by spectral data on the pine needles extract as

Table 1. Stem diameter, node length and leaf area on several agroforestry systems

\begin{tabular}{lccc}
\hline Agroforestry system & Stem diameter, cm & Node lenght, $\mathrm{cm}$ & ${\text { Leaf area, } \mathrm{cm}^{2}}^{2}$ \\
\hline Without shading & $22.9 \mathrm{ab}$ & $6.8 \mathrm{~b}$ & $133.0 \mathrm{~b}$ \\
Coffee-Natural forest & $25.4 \mathrm{a}$ & $9.1 \mathrm{a}$ & $150.5 \mathrm{~b}$ \\
Multistrata & $26.7 \mathrm{a}$ & $8.8 \mathrm{a}$ & $166.1 \mathrm{ab}$ \\
Coffee-Pine & $18.4 \mathrm{~b}$ & $8.8 \mathrm{a}$ & $145.6 \mathrm{~b}$ \\
Coffee-Paraserianthes & $22.3 \mathrm{ab}$ & $8.0 \mathrm{ab}$ & $181.3 \mathrm{a}$ \\
Coffee-Leucaena & $27.2 \mathrm{a}$ & $7.3 \mathrm{~b}$ & $165.7 \mathrm{ab}$ \\
\hline Notes: Data on the same column followed by the same letter were not significanly different according to Duncan 5\%.
\end{tabular}


$9 \alpha, 13 \beta$ - epidioxyabeit-8(14)en-18-oic acid and abscisic acid- $\beta$-Dglucopyranosyl ester (Kimura et al., 2015).

The longest nodes segment was found in the coffee forest with an average of $9.1 \mathrm{~cm}$, while the shortest node occurred on coffee without shade $(6.8 \mathrm{~cm})$. Longer branches and nodes length had been observed in coffee grown under shade trees in Cuba (Rodríguez et al., 2001) due to low degradation of auxin (Salisbury \& Ross, 1995). The same result mentioned by Campanha et al. (2004) that coffee plants in agroforestry system had branches $68.1 \mathrm{~cm}$ long with 25 nodes, compared to branches $83.2 \mathrm{~cm}$ long with 34 nodes in the monoculture coffee plants. Coffee plants in the agroforestry system had more persistent leaves, evidenced by less leaf formation and leaf fall, but plants in monoculture had a greater number of leaves.

Light intensity can affect plant form, flowering, leaf size, and color in both herbaceous (Jeong et al., 2009; Vendrame et al., 2004) and woody species (Hampson et al., 1996). In this research, leaf area of the coffee plants showed significant difference among the treatments. Coffee without shading showed the smallest leaf area and thicker leaves than any other treatment caused by high-intensity radiation (Jaramillo-Botero et al., 2009). Low Irradiation on coffee agroforestry cause wider leaf area than without shading treatment. Coffee plants under Parasianthes sp, Leucaena sp, and multistrata showed a wider area than any other treatment because of the shade plants including on the legumes group were able to provide extra nitrogen for coffee trees. Coffee plants on agroforestry sistem had greater uniformity in leaf dimension during the dry season and rainy season. In dry season plants in agroforestry system had an average leaf area of $55.2 \mathrm{~cm}^{2}$ leaf ${ }^{-1}$, compared to $36.4 \mathrm{~cm}^{2}$ leaf $^{-1}$ in coffee without shading. At rainy season, the coffee plants in coffee without shading had a leaf area of $63.3 \mathrm{~cm}^{2} \mathrm{leaf}^{-1}$, compared to $53.1 \mathrm{~cm}^{2}$ leaf $^{-1}$ in agroforestry system coffee plants.

Levels of chlorophyll a, chlorophyll b and total chlorophyll in leaves of coffee without shade indicated that the value of the lowest compared to other treatments. While chlorophyll a, chlorophyll $\mathrm{b}$ and total chlorophyll in leaves of coffee under forest showed a higher value than the other interventions. Results of research Pompelli et al., (2010) showed the differences in chlorophyll content of leaves on Robusta coffee obtained light intensity by 50 and $100 \%$. Chlorophyll content of leaves of coffee plants that get the light intensity by $50 \%$ higher than the coffee plants which obtained full light intensity. Similar results were also expressed by (Ristiawan, 2011) that the levels of chlorophyll $\mathrm{a}$ and $\mathrm{b}$ in coffee leaves under Leucaena sp. with $79.55 \%$ of light intensity is less than the leaf chlorophyll content of coffee planted under Paraseriantes sp. which had a light intensity $52.25 \%$. Differences in leaf chlorophyll content caused by the intensity of radiation that was received by the coffee plants (Gardner et al., 1991).

Table 2. Chlorophyl content on the coffee leaves

\begin{tabular}{lccc}
\hline \multirow{2}{*}{ Agroforestry system } & \multicolumn{1}{c}{ Chlorophyll, mg/L } \\
\cline { 2 - 4 } & $\mathrm{a}$ & $\mathrm{b}$ & Total \\
\hline Without shading & $135.0 \mathrm{c}$ & $79.29 \mathrm{c}$ & $184.0 \mathrm{c}$ \\
Coffee-Natural forest & $152.0 \mathrm{a}$ & $86.08 \mathrm{a}$ & $205.0 \mathrm{a}$ \\
Multistrata & $145.0 \mathrm{~b}$ & $83.37 \mathrm{~b}$ & $196.6 \mathrm{~b}$ \\
Coffee-Pine & $143.8 \mathrm{~b}$ & $82.88 \mathrm{~b}$ & $195.1 \mathrm{~b}$ \\
Coffee-Paraserianthes $s p$ & $140.2 \mathrm{~b}$ & $81.43 \mathrm{~b}$ & $190.6 \mathrm{bc}$ \\
Coffee-Leucaena sp & $143.2 \mathrm{~b}$ & $82.64 \mathrm{~b}$ & $194.4 \mathrm{~b}$ \\
\hline Notes: Data on the same column followed by the same letter were not significantly different according to Duncan MRT at 5\% significance
\end{tabular}




\section{Productivity}

Type of agroforestry affects the intensity of the light received by the coffee plants. The coffee grown under shade, the outer leaf canopy will receive enough light for photosynthesis, while the leaves inside the canopy does not. Impact of the rate of photosynthesis is that assimilate production is generated and stored in the coffee cherries. In addition, low intensity of light cause negatively affect on flowering and decelerate fruit ripening (Kimenia \& Njoroge, 1988; Severino \& Oliveira, 1999). The condition of coffee fruiting at the time of El Nino in some agroforestry systems is shown in Table 3.

Number of productive branches is one of the factors that affect productivity. From the observation it can be seen that the number of productive branches in various agroforestry systems showed a signicantly difference that is in the range of 19.74-23.82 except in coffee grown with pine. This has been reported in the observation of vegetative growth that showed that coffee growth under the pine was inhibited.

In normal condition, the shading of coffee trees increased the effects of selfshading in reducing flower bud differentiation in the inner parts of the tree (Da Matta, 2004). However, during El Nino period, coffeeforest and coffee-Leucaena sp produced nodes per branch, respectively, 8.78 and 8.56 more than other treatments that ranged from 6.78 to 7.67 . It is allegedly related to the ability of shade trees in the two systems to maintain canopy condition does not fall out during the El Nino. Soil fertility and soil humidity in the coffee-forest was higher than other location because of the litter. In the coffee-Leucaena productive branch growth was enhanced by increased nitrogen content due to the activity of Rhizobium bacteria symbiotic mutualism with Leucaena roots. Rhizobium will fix free nitrogen from the air then this nitrogen will be placed on the ground with nitrogen up to $110 \pm 30$ $\mathrm{kg} \mathrm{ha}^{-1} /$ year (Hogberg \& Kvarnstrom, 1982). Carbon assimilation becomes lower due to excessive shade, so the vegetative growth becomes more dominant than the appearance of flower buds (Cannell, 1985; Da Matta, 2004). Multistrata, coffee-pine and coffee-Parasianthes produced branches with a number of segments slightly allegedly related to high competition to get nutrition and light. Meanwhile the coffee without shade plants experienced severe stress due to light, soil moisture and air humidity.

Coffee-forest and coffee-Leucaena produced number of cherries per node more than other treatments, respectively, of 17.17 and 16.14 cherries per node during El Nino period. The ability of agroforestry to maintain moisture and temperature in the system is suspected as the cause. Unshaded coffee trees usually have a greater accumulation of dry mass, since the high load of berries stimulates photosynthesis and the formation of new nodes (Cannell, 1985; Da Matta, 2004). A relatively high temperature during blossom, especially if associated with a

Table 3. Effects of several agroforesty systems on number of productive branches, nodes, and cherries

\begin{tabular}{lcccc}
\hline Agroforestry & Productive branches & Nodes per branch & Cherries per node & Cherries per tree \\
\hline Without Shading & $22.12 \mathrm{a}$ & $7.67 \mathrm{~b}$ & $15.47 \mathrm{ab}$ & $2237 \mathrm{a}$ \\
Coffee-Natural forest & $22.04 \mathrm{a}$ & $8.78 \mathrm{a}$ & $17.17 \mathrm{a}$ & $3241 \mathrm{a}$ \\
Multistrata & $23.82 \mathrm{a}$ & $6.78 \mathrm{~b}$ & $12.01 \mathrm{~b}$ & $1461 \mathrm{a}$ \\
Coffee-Pine & $15.91 \mathrm{~b}$ & $7.33 \mathrm{~b}$ & $14.06 \mathrm{~b}$ & $1336 \mathrm{~b}$ \\
Coffee-Paraserianthes sp. & $19.74 \mathrm{ab}$ & $7.11 \mathrm{~b}$ & $14.70 \mathrm{~b}$ & $1630 \mathrm{ab}$ \\
Coffee-Leucaena sp. & $22.92 \mathrm{a}$ & $8.56 \mathrm{a}$ & $16.14 \mathrm{a}$ & $3012 \mathrm{a}$ \\
\hline Notes: Data on the same column followed by the same letter were not significanly different according to Duncan 5\%.
\end{tabular}


prolonged dry season, may cause abortion of flowers (Lin, 2008) and causes decrease in number of cherries per node. The impact seen in the coffee grown under natural forest produced highest number of cherries per tree than the other systems.

Observations on productivity per hectare were carried out for fruiting in 2016, as the result of flowering in 2015 where there was a long drought due to El Nino period. Microclimate at the time of flowering and fruit development was dry with high temperatures, however, the coffee under shade indicate higher productivity.

According to the observations, productivity of Robusta coffee in Gumitir Mountain area duuring El Nino showed that the highest productivity in forest $1497 \mathrm{~kg} \mathrm{ha}^{-1}$ compared with $1355 \mathrm{~kg} \mathrm{ha}^{-1}$ on coffee grown under Leucaena. This was not in line with several studies that had been done showed that coffee yields in agroforestry system were either poorly recorded or very low, when compared to conventional Brazilian coffee yields (Oliveira 1999; Soto et al., 2000; Cardoso et al., 2001). The coffee crop in the agroforestry system was less productive than the coffee without shading, yielding $514.8 \mathrm{~kg} \mathrm{ha}^{-1}$ of dry berries, compared with $2442.8 \mathrm{~kg} \mathrm{ha}^{-1}$ found in coffee without shading. However, in another research concluded that in some situations, shade trees favored the coffee crop, increasing its productivity (Oliveira, 1999; Soto et al., 2000). The same results obtained in the state of Chiapas, Mexico, where the yields of high-shaded coffee (60-
$80 \%)$ and medium-shaded coffee (30-50\%) were similar, around $1,600 \mathrm{~kg} \mathrm{ha}^{-1}$, although data were taken for just one year (Lin, 2009).

Coffee grown under forest and CoffeeLeucaena showed the highest productivity during El Nino because their ablility to maintain and retain moisture. In Gumitir mountain area, coffee grown under forest with a population 10-20 trees per hectare, a height of over than $50 \mathrm{~m}$, with deep roots, it caused minimum nutrient, water and light competition. Coffee grown under Leucaena planted by Indonesian standard cropping patterns ensured the availability of space for the coffee plants. This system is also an ideal way of organic farming as the leaf and other falls of the tree shade will add to organic matter content of the soil by contributing organic biomass through the litter (Alemu, 2015). The effect of natural shading on the microclimate of coffee crop in relation to plant growth, yield and beverage quality has been studied in several situations (Baggio et al., 1997; Barradas, 1986; Beer et al., 1998; Peeters et al., 2003) and leading to more steady production, soil protection, and a more favorable microclimate (Barros et al., 1995).

Coffee without shade produced higher productivity than multistrata, coffee-Paraserianthes and coffee-pine. High productivity on the coffee without shade because of high soil fertility on this location, but without good nutrient inputs coffee without shade will not be sustainable (Evizal et al., 2009). While on the multistrata, coffee-Paraserianthes

Table 4. Coffee trees population, productive trees cherry per ha and productivity per hectare

\begin{tabular}{lccrr}
\hline Agroforestry & Trees population/ha & Productive trees & Cherries/ha & Productivity (kg/ha) \\
\hline Without shading & $1,757 \mathrm{a}$ & $1,497 \mathrm{a}$ & $3,348 \mathrm{ab}$ & $1,005 \mathrm{~b}$ \\
Coffee-Natural forest & $1,656 \mathrm{a}$ & $1,540 \mathrm{a}$ & $4,990 \mathrm{a}$ & $1,497 \mathrm{a}$ \\
Multistrata & $1,521 \mathrm{a}$ & $1,146 \mathrm{~b}$ & $1,674 \mathrm{~b}$ & $502 \mathrm{c}$ \\
Coffee-Pine & $1,551 \mathrm{a}$ & $1,263 \mathrm{~b}$ & $1,686 \mathrm{~b}$ & $506 \mathrm{c}$ \\
Coffee-P. falcataria & $1,630 \mathrm{a}$ & $1,287 \mathrm{~b}$ & $2,097 \mathrm{~b}$ & $\mathrm{c}$ \\
Coffee-Leucaena sp & $1,648 \mathrm{a}$ & $1,499 \mathrm{a}$ & $4,515 \mathrm{a}$ & $1,355 \mathrm{a}$ \\
\hline Notes: Data on the same column followed by the same letter were not significanly different according to Duncan 5\%.
\end{tabular}


and coffee-pine, coffee trees facing a great competition to get nutrients and water caused by a large number populations of shade trees with irregular cropping patterns.

\section{CONCLUSION}

Agroforestry system in coffee is able to maintain environmental conditions for variable of irradiation, temperature and moisture during El Nino period it caused stability of plant growth and coffee productivity. Coffee agroforestry systems with pine showed the smallest stem diameter and fewer productive branches. It is suspected due to the presence of allelopathy compounds released by the litter of pine leaves. The effect of natural shading on the microclimate of coffee crop in relation to plant growth, and yield has been studied in several situations and leading to more steady production and a more favorable microclimate. A closer understanding of the interactions among species and agroclimate how those interactions affect the mechanisms responsible for coffee productivity is needed in order to design agroforestry systems, which produces reasonable coffee yields compared to those found on unshaded coffee.

\section{REFERENCES}

Alegre, C. (1959). Climates et cafeiers d'arabic. Agronomy Tropical, 14, 25-48.

Alemu, M.M. (2015). Effect of tree shade on coffee crop production. Journal of Sustainable Development, 8, 66-70.

Baggio, A.J.; P.H. Caramori; A.A. Filho \& L. Montoya (1997). Productivity of southern Brazilian coffee plantations shaded by different stockings of Grevillea robusta. Agroforestry Systems, 37, 111-120.

Barradas, V.L. \& L. Fanjul (1986). Microclimatic characterization of shaded and opengrown coffee (Coffea arabica L.) plan- tations in Mexico. Agricultural and Forest Meteorology, 38, 101-112.

Barros, R.S.; M. Maestri \& A.B. Rena (1995). Coffee crop ecology. Tropical Ecology, $36,1-19$.

Beer, J.W. (1992). Production and competitive effects of the shade trees Cordia alliodora and Erythrina poeppigiana in an agroforestry system with Coffea arabica. University of Oxford, Oxford, United Kingdom.

Campanha, M.M.; R.H.S. Santos; G.B. de Freitas; H.E.P. Martinez; S.L.R. Garcia \& F.L. Finger (2004). Growth and yield of coffee plants in agroforestry and monoculture systems in Minas Gerais, Brazil. Agroforestry Systems, 63, 75-82.

Cannell, M.G.R. (1985). Physiology of the coffee crop. p. 108-134. In: M.N. Clifford \& K.C. Willson (Eds.). Coffee: Botany, Biochemistry and Production of Beans and Beverage. Croom Helm, London, UK.

Cardoso, I.M; I. Guijt, F.S. Franco, P.S. Carvalho \& P.S. Ferreira (2001). Continual learning for agroforestry system design: university, NGO and farmer partnership in Minas Gerais, Brasil. Agricultural Systems, 69, 235-257.

DaMatta, F.M. (2004). Ecophysiological constraints on the production of shaded and unshaded coffee: A review. Field Crops Research, 86, 99-114.

Ditjenbun (2010). Statistik Perkebunan Indonesia (Kopi). Direktorat Jenderal Perkebunan, Jakarta.

Erdiansyah, N.P. \&F. Yuliasmara (2016). Pengelolaan penaung. In: Kopi: Sejarah Botani Proses Produksi, Pengolahan, Produk Hilir dan Sistem Kemitraan (Wahyudi, Pujiyanto \& Misnawi), Gadjah Mada University Press, Yogyakarta.

Erdiansyah, N.P. \& Yusianto (2012). Relationship between caffeine content and flavor with light intensity of several coffee 
Robusta clones. Pelita Perkebunan, 28, 14-22.

Evizal, R.I.; D. Tohari; J. Prijambada; D. Widada \& Widianto (2009). Biomass production of shade-grown coffee agroecosystems. Proceeding International Seminar on Sustainable Biomass Production and Utilization Challenges and Oppurtunities (ISOMASS). Bandar Lampung, 3-4 August 2009.

Fournier, L.A. (1987). Coffee cultivation (Coffea arabica L.) in open sun and shade: An agronomic and ecophysiologic focus). Agronomía Costarricense, 12, 131-146.

Gardner, F.P.; R.B. Pearce \& R.L. Mitchell (1991). Physiology of Crop Plants. Universitas Indonesia Press. Jakarta.

Garrett, H.; W. Rietveld \& R. Fisher (2000). North American Agroforestry: An Integrated Science and Practice. ASA, Madison.

Garrity, D. (2004). Agroforestry and the achievement of the millenium development goals. Agroforestry Systems, 61, 5-17.

Hairiah, K.; S. Rahayu \& Berlian (2006). Layanan lingkungan agroforestri berbasis kopi: Cadangan karbon dalam biomasa pohon dan bahan organik tanah (Studi kasus dari Sumberjaya, Lampung Barat). Agrivita, 28, 298-309.

Hammer, G.L.; D.P. Holzworth \& R. Stone (1996). The value of skill in seasonal climate forecasting to wheat crop management in a region with high climatic variability. Australian Journal of Soil Research, 47, 717-737.

Högberg, P. \& M. Kvarnström (1982). Nitrogen fixation by the woody legume Leucaena leucocephala in Tanzania. Plant and Soil, 66, 21-28.

Hulupi, R. (1999). Bahan tanam kopi yang sesuai untuk agroklimat di Indonesia. Warta Pusat Penelitian Kopi dan Kakao, 15, 64-81.

Jaramillo-Botero, C.; R.H.S. Santos; H.E.P Martinez; P.R. Cecon \& M.P. Fardin (2009). Production and vegetative develop- ment of coffee trees grown under solar radiation and fertilization levels, during years of high and low yield. AmericanEurasian Journal of Agricultural and Environmental Science, 6, 143-151.

Jeong, K.Y.; C.C. Pasian; M. McMahon \& D. Tay (2009). Growth of six Begonia species under shading. Open Horticultural Journal, 2, 22-28.

Kimenia, J.K. \& J.M. Njoroge (1988). Effect of shade on coffee-A Review. Kenya Coffee, 53, 387-391.

Kimura, F.; M. Sato, \& H. Kato-Noguchi. (2015). Allelopathy of pine litter: Delivery of allelopathic substances into forest floor. Journal of Plant Biology, 58, 61-67.

Kumar, D. \& L.L. Tieszen (1980). Photosynthesis in Coffea arabica L. Effects of light and temperature. Experimental Agriculture, $16,13-19$

Larcher, W. (2000). Ecologia Vegetale. Trad. de C.H.B.A. Prado. São Carlos. Rima.

Lin, B.B. (2007). Agroforestry management as an adaptive strategy against potential microclimate extremes in coffee agriculture. Agricultural and Forest Meteorology, 144, 85-94.

Lin, B.B. (2008). Microclimate effects on flowering success in coffee agroforestry systems. American-Eurosian Journal of Agriculture and Environmental Science, 3, $148-152$.

Lin, B.B. (2009). Coffee (Café arabica var. Bourbon) fruit growth and development under varying shade levels in the Sonocusco region in Chiapas, Mexico. Journal of Sustainable Agriculture, $33,51-65$.

Macedo, R.L.G.; N. Venturin \& A.A. Tsukamoto Filho (2000). Agroforestry principles as support for sustainable management. Informe Agropecuário, 21, 93-98.

Muschler, R.G. (2001). Shade improves coffee quality in a sub-optimal coffee-zone of Costa Rica. Agroforestry Systems, 51, 131-139. 
Nair, P.; B. Kumar \& V. Nair (2009). Agroforestry as a strategy for carbon sequestration. Journal of Plant Nutrition and Soil Science, 172, 10-23.

Nektarios, P.A.; G. Economou \& C. Avgoulas (2005) Allelopathic effects of Pinus halepensis needles on turfgrasses and biosensor plants. HortSci, 40, 246-250.

Peeters, L.Y.K.; L. Soto-Pinto; H. Perales; G. Montoya \& M. Ishiki (2003). Coffee production, timber and firewood in traditional and Inga-shaded plantations in Southern Mexico. Agriculture, Ecosystems and Environment, 95, 481-493.

Pereira, A.T. \& G.N. Pereira (2009). Shade Grown Ecofriendly Indian Coffee.

Pezzopane, J.R.M.; P.B. Gallo \& A.A. Ortolani (2000). Microclimatic characterization in intercropped Arabica coffee. Proceedings of $1^{\text {st }}$ Symposium of Researches of Brasilian Coffee, 72-75. EMBRAPA Café/MINASPLAN, Brasília, DF, Brazil.

Pompelli, M.F.; S.C.V. Martins; W.C. Atunes; A.R.M. Chaves \& F.M. DaMatta (2010). Photosynthesis and photoprotevtion in coffee leaves is affected by nitrogen and light availabilities in winter conditions. Journal of Plant Physiology, 167, 1052-1060.

Rena, A.B. \& M. Maestri (1986). Coffee physiology. p. 87. In: A.B. Rena; E. Malavolta; M. Rocha \& T. Yamada (Eds.), Coffee Crop: Factors Affecting Productivity. Associação Brasileira para a Pesquisa da Potassa e do Fosfato, Piracicaba, Brazil.

Ristiawan, A.P. (2011). Karakter Fisiologis Dua Klon Kopi Robusta pada Jenis Penaung yang Berbeda. Skripsi. Universitas Jember, Jember.

Rodríguez, L.A.; V. Orozco; E. Velasco; R. Medina; J. Verdecia \& I. Fonseca (1999). Optimum sun light levels and its relation with vegetative growth, leaf development and coffee productivity (Coffea arabica L.). Cultivos Tropicales, 20, 45-49.
Salisbury (1995). Fisiologi Tumbuhan Jilid 2. ITB, Bandung.

Severino, L.S. \& T.S. Oliveira (1999). Coffee shade cultivation systems (Coffea arabica L.) in Baturité region, Ceará, Brazil. Revista Ceres, 46., 635-652.

Soto, P.L.; I. Perfecto; H.J. Castillo \& N.J. Caballero (2000). Shade effect on coffee production at the northern Tzeltal zone of the state of Chiapas, México. Agriculture Ecosystems \& Environment, 80, 61-69.

Suryanto; P. Budiadi \& S. Sabarnurdin (2005). Agroforestri. Fakultas Kehutanan. Universitas Gadjah Mada. Yogyakarta.

Sylvain, P.C. (1958). Ethiopian coffee - Its significance to world coffee problems. Economy Botany, 12, 111-139.

Thomaziello, R.A.; L.C. Fazuoli; J.R.M. Pezzopane; J.I. Fahl \& M.L. Carelli (2000). Arabic Coffee: Culture and Techniques of Production. Instituto Agronômico, Campinas, Brazil.

Trenberth, K.E. (1997). The definition of El Niño. Bulletin of the American Meteorological Society, 2771-2777.

Vaast, P.; B. Bertrand; J.J. Perriot; B. Guyot \& M. Génard (2006). Fruit thinning and shade improve bean characteristics and beverage quality of coffee (Coffea arabica L.) under optimal conditions. Journal of the Science of Food and Agriculture, 86, 197-204.

Vendrame, W.; K.K. Moore \& T.K. Broschat (2004). Interaction of light intensity and controlled-release fertilization rate on growth and flowering of two New Guinea impatiens cultivars. HortTechnology, 14, 491-495.

Wibawa, A.; F. Yuliasmara \& R. Erwiyono (2010). Estimasi cadangan karbon pada perkebunan kopi di Jawa Timur. Pelita Perkebunan, 26, 1-11.

Williams-Guillen, K.; I. Perfecto \& J. Vandermeer (2008). Bats limits insects in a neotropical agroforestry system. Science, 320, 58-72.

$* * 0 * *$ 